ISSN- 2394-5125

\title{
OTHERING THE SELF AS A FORM OF MIMICRY IN THE ENGLISH TRANSLATION OF HIRATA'S LASKAR PELANGI
}

\author{
Prasuri Kuswarini' ${ }^{1}$, Muhammad Hasyim², Irma Nurul Husnal Chotimah ${ }^{3}$ \\ ${ }^{1,2,3}$ Universitas Hasanuddin, Makassar, Indonesia \\ E-mail: p.kuswarini@fib.unhas.ac.id
}

\begin{abstract}
Indonesia's best-seller novel, Laskar Pelangi (LP) by Andrea Hirata, is praised as a masterpiece that dares to show educational inequality in Indonesia, but at the same time is scolded for being too Westernoriented. The translation of this novel, Hirata himself made the draft, was assumed and suspected of being designed to amuse Western readers. It is very relevant for this paper to discuss the English translation of the novel from the post-colonial perspective. As the initial translator, Hirata significantly modified the English translation with addition (and deletion) of words, phrases, sentences, paragraphs, and a new sub-chapter. The shifts are examined with post-colonial theories from Said and Bhabha to reveal thetranslator's standpoint to the issue of Self and Other in the context of West-East relation. The point is also seen from a social perspective with the approach of Oysterman and Marcus's theory about the 'Social Self' (and Other), with the consideration that the author himself made the initial translation. The results of the analysis show a phenomenon of mimicry in the form of othering the self through hyperbolic descriptions of poverty, castration of Malay Islamic tradition, and creation of a local female hero. This study will empower translators from ex-colonized countries to be more concerned about their dignity, identity and uniqueness for promoting equality in translation.
\end{abstract}

KEYWORDS: Andrea Hirata; The Rainbow Troops;Mimicry;Post-colonial Translation; Self and Other

\section{INTRODUCTION}

This paper is an elaboration of a former article entitled Stereotyping the Self in the English translation of LaskarPelangi: A Post-Colonial Analysis, presented at the $6^{\text {th }}$ ASBAM Seminar, (annual seminar on Archaeology, History, Language and Culture of Malay World organized by a collaboration between the HasanuddinUniversity, Makassar, Indonesia, and Malaysia) in Johor Bahru Malaysia. This article used the same data, but changed, and addedthe literature review to refine the theoretical approaches, results, and conclusion. The literature review comprises definitions, opinions related to the concept of mimicry in post-colonial theory, social and post-colonial concepts of Self and Other, and several results of researchesdiscussing self-translation from a post-colonial perspective.

The theory of post-colonialism switches on our awareness that inequality in the relationship between the West (former colonizers) and the East (ex-colonized countries) still happensafter colonialism(Arafah, B. \& Hasyim, M. 2019). The connectionreflects power relations. The West still dominates the world through language, living standards, and values, law, etc., and a try to maintain its dominance over their ex-colonies through the reasons such:”... Civilizing Mission or the White Man's Burden...” (Bhabha, 1994, p. 83).

On the other hand, the ex-colonized countries alert, that they need their own 'stage' to express their existence but they still swing between "the demand for identity" (Said qt. In Bhabha, 1994, p. 86), namely the effort to define self-identity, and the difficulty of escaping themselves from the colonial value that firmly affects their way of lifeand thought. The Dutch legacy of law products in Indonesia is an example. Indonesia is a very heterogeneous country, where the people live a communal life, but governed by the law produced by the colonial and individual Dutch (Maroni, 2012, p. 89). The people are aware that they need to develop their legislationand put the base on their nature as a pluralistic nation, but until today the inherited law still exists.

Andrea Hirata, a writer of several best-seller Indonesian pop novels, described in his first novel Laskar Pelangi, in an adoring way, idyllic European (western) lifestyle adopted by the precious high ranked staff of a tin company in Belitong Island, near Sumatra:

ST: Di dalam rumah utama sang majikan terdapat ruang tamu dengan lampu-lampu yang teduh...di sana ada sofa Victorian Rosewood,... Di meja makan mewah dengan kayu cinnamon glaze, mereka duduk mengelilingi makanan...pumpkin and gorgonzola soup, 1286aesar salad....chicken cordon bleu, viello ala Provenzale,... makanan penutup adalah 


\section{JOURNA OF CRITICAL REVIEWS}

ISSN- 2394-5125

VOL 7, ISSUE 19, 2020

creamy cheesecake topped with strawberry puree, .... . Mereka makan dengan tenang sembari mendengarkan 1287aesa klasik yang elegan: Mozart: Haffner No. 35 in D Major. (LP, p. 44) (Inside the main house of the employer there was a living room with shady lights ... there stood Victorian sofa made of Rosewood, ... on a luxury dining table made of a wood called the cinnamon glaze, they sat around the food ... pumpkin and gorgonzola soup, 1287aesar salad .... chicken cordon bleu, viello ala provenzale, ... the dessert was creamy cheesecake topped with strawberry puree, ... They quietly ate while listening to elegant classical music: Mozart: Haffner No. 35 in D Major).

The way Hirata narrated the situation shows that the will to imitate the dominant colonizer stay deep under the consciousness of the ex-colonized people. They see that Europe or the West is still the perfect orientation for living standards. Bhabha calls it mimicry, imitation. That is a phenomenon seen as a successful mission of the West influencing the East (Bhabha, 1994). He describes this phenomenon as a "desire" for a reformed, recognizable Other, as a subject of a difference that is almost the same but not quite" (1994, p. 86). It means that the Other cannot replicate the Self.The Self seems ever superior and maintains its dominance over the Other, the ex-colonized countries, politically, culturally (Khanal, 2012, p.2), and racially(Callahan, 2015,p. 251). Bothsides internalizethe nature of this relationship into their worldview or the way they think about each other (Kaharuddin, A. 2018).

The issue of Self and Other is also a challenging object of translation studies since it involves the unequal position of languages of former colonial rulers and colonized countries. Translation in a post-colonial context affect quiet often the problem of ideological conflict between one of the source text (ST) and the other of the target text (TT), furthermore when the translator is the author him/herself, called as 'self-translation.' Self-translation often builds a dilemma when the author comes from an ex-colonized country and translates his/her work into the language of the former colonizer. Thus, for many bilingual writers, forexample, those from ex-colony countries, self-translation is a challenging experiment. They translate their works in such ways that the adopted language does not obscure the identity of their nation and its values.

Representative examples of self-translation are what a Kenyan writer,Ngugiwa Thiong'O, and several Pakistani's, like Irshad Abdul Kadir, Sidrah Haque, and Nadeem Qasimi, did. They used the strategy: "reinforces their literary/rhetorical agenda."They negotiated their cultural and ideological identity with the dominant target-language for avoiding the loss of their cultural and particular linguistic-identity (Andindilile, 2013, p. 194; Shamsie, 2011, p. 119). This translation strategy is carried out, for example, by authors from African and some Asian countries who are used to communicating bilingual (local languages and European/ Western languages, such as French and English).

Instead of negotiating local culture with a dominant language, Gjurčinova sees the use of adopted language in self-translation as 'tool' for migrant writers who write and translate their works in the chosen language: "to get him/herself out of isolation... also a "littérisation" ... to be regarded as literary" (Gjurčinova, 2013, p.5).These different motives of using dominant language in self-translation,in general, reveal the relationship between language and power.

Many postcolonial authors have received a Western education and have unconsciously inherited Western ways of thinking. But, according to the explanation, we can see that they are also aware that they should give the world the right and clear picture of their existence, their identity, and uniqueness. Selftranslation can realizethe action through the use of a dominant (i.e., ex colonizer's) language creatively and wisely for not hurting the dignity of their nation. Therefore, many postcolonial studies have also been carried out on translation to reveal how a translation (mainly literary works) presents the concept of the Self and the Other in TT. Such research can show how a translator behaves towards the idea.In such a context, the point of view must bechanged; the Self is the author who acts as the translator and becomes a mediator for the Other, namely the TT readers, the ex-colonizer.

This article examines the self-translation by Andrea Hirata for his best-selling novel (LP) into English entitled The Rainbow Troops (TRT). Although Hirata eventually used the services of another translator, Angie Kilbane, the initial draft of the translation came from himself. The following quotation is from Angie Kilbane's note:

[...] A few months later, Andrea asked me to review two drafts of translations for the book. I gave him my opinion, and he eventually asked me if I would translate it. [...] Andrea himself has had a very active role in the translation. We have had many ups and downs while working on this project, and it would not be anywhere near as good as it is without him (TRT, p. 469).

Some Indonesian researchers criticized the translation of LP to TRT because of significant modifications in the level of information, in the form of reduction, addition, even 'demolition' (Yasin etal., 2018, pp. 58-59). Culturally, the translation is also rated as weak because it overlooked many metaphors that 


\section{JOURNA OF CRITICAL REVIEWS}

ISSN- 2394-5125

VOL 7, ISSUE 19, 2020

signify Indonesian culture (Adibah, 2012, Kaharuddin, A., \& Latif, I. 2017). It is suspicious that the significant changes are a kind of design for gaining particularreactions from the TT- (west)readers. International critics judged the translation of LP to TRT is differed far from the original forsharpeningsocialcriticismtoacquiremore positive responsesfrom globalsociety(David,2016). It is then interesting to find out how the translator who is at the same time the author himself, brought his message or idea to the Western reader. Thus, the use of the postcolonial approach is needed.

\section{THE SOCIAL AND POSTCOLONIAL CONCEPT OF SELF AND OTHER}

Self is a being of cognition in the structure of consciousness. Alonzo states: "the self-concept is what we think about the self; self- value the positive or negative evaluations of the self, as in how we feel about it" (2019, p. 82). The concept sees the Self from one side, specifically from within such as awareness, feelings, memories. It is very individualistic, like closed space, separated from the outside world (Sohrabi \& Pirnajmuddin, 2017, p. 15). The concept emphasizes the differences or uniqueness that each individual has.

The definition of Self, based on the perspective of the outside (Other), is a social concept. Leary \& Tangney concluded that the Self is seen and judged by others. The self-concept contains cognitive aspects from the inner side; it is also influenced by social issues that work through experiences gained from the outside world (. This self-concept affects someone's opinion against him/herself (the self) and others(2012, p. 71).

The terms Self and Other became an integral part of the post-colonial study. That is a theory of discourse which purpose is to find traces of European (West) colonialism in the East (ex-colonized countries), and its impacts on different aspects of life of people from ex colonized countries, and their appearances in Western literature and philosophical inheritance(Hamadi, 2016, p. 40). Postcolonial theory is widely known based on, among others, Edward Said's book Orientalism. Said explained that colonialism became the way for Europeans (West) to identify themselves as the Self and the colonies such as Asia or Africa (East) as the Other. In post-colonialism, the relationship between the Self and the Other perceived as the relationship of power, domination and hegemony in which the Self is those who have the power to determine the position of themselves and the Other (Said, 2003, pp. 1-3). The Self assumes 'themselves' superior to the Other, and the Other 'takes their fate' and seems to have the difficulty for breaking away from the image given to them by the Self as the subordinated party. That is thephenomenon of 'Slavery of the minds', or in the word of Zawiah: “... the fact that the 1288olonized succeeded in convincing the 1288olonized of their own inadequacies" (Chandran \& Vengadasamy, 2018, p. 18).

Slavery of the mind shows its shape in the form of mimicry of the Self's attitude or behavior by the Other. The most obvious example of mimicry is the imitation of lifestyle such as dressing, housing, consumption, to language use. But what is often not realized is the imitation of the Self's attitude, used to judge his/her fellow. Socially, but seen from a post-colonial perspective, this attitude can be considered as an act of Othering the Self.

In this study, the concept of the Self rests on a social foundation, according to Oysterman's explanation and the perspective of postcolonialism. The Selfanalyzed in this study is represented by the translation of LP by the author himself.

LP was translated into English under the title 'The Rainbow Troops' (TRT). The translation represents thesocialSelf. Viewed from a postcolonial perspective it is the representation of the East. The English translation of LP is for readers in countries using English, which, according to the postcolonial view, represents the West, but socially it is the Other.

\section{THE ISSUE OF (IN) EQUALITY INPOSTCOLONIAL TRANSLATION}

The Issue of (in) equality in translation could be started with Derrida's reflection that language is unstable, that meaning is always vague, manifold, and extensive (Andrade, 2016). Extending Derrida's thought, Foucault asserts that meaning still relates to history and specific circumstances. A meaning of anutterance depends on the time and the place, when and where it is uttered, who states it, and to whom it is aimed. He declares that language is also tightly connected to power: who speaks what to whom, in what circumstance, signify subjectobject relations or relations between the controlling and the controlled in a particular context (Barker, 2003, pp. 17-19). Following Foucault, Habermas claims that: "Language is also a medium of domination and social power. It serves to legitimate relations of organized force... "(in Bandia, 2008, p. 139). The discourse about inequality in the subject of translation can be referred to Talal Asad's argumentation that "translation is a process of power." "Translators merge themselves into the world of others hastily and recognize the inequality of the position of language and culture seen as special textual entities that can only be read and translated for Western-educated people" (qt. in Orsini \& Srivastava, 2013, p. 324). According to Asad, the power structure that the colonized translator must face is more institutional than textual (qt. in Shamma, 2009, p. 192). 


\section{JOURNA OF CRITICAL REVIEWS}

ISSN- 2394-5125

VOL 7, ISSUE 19, 2020

(In)Equality is a common issue in translation, especially translation of the texts connected to the relationship between the West and the East, between the Self and the Other, between the dominant power and the subordinated.Muldoon, an Irish translator, promotes equality in translation through the strategies of subversive literalism and paratextual explanation that help the Irish language and its attendant culture (Kirkley, 2013, p. 290). The target language readers in Poland support the efforts of postcolonial translators to achieve equality. They found that: "translated postcolonial narratives ..., going against the grain of a long tradition of 'othering' attitudes to postcolonial non-Europeans and marking a new ... way to Polish-postcolonial solidarity" (Goluch, 2018, p.17). It means that postcolonial translation is a translation promoting equality.

Regarding the discourse on inequality in language practices, Habermas proposes the concept of an ideal speech situation, in which human applies language as a representative who takes part in a public speech (Andi, K., \& Arafah, B. 2017, Kaharuddin., \& Hasyim, M. 2020). One should take part in a speech community for being accepted as an agent (Maknun, T., Hasjim, M., Muslimat, M., \& Hasyim, M. 2019). As an agent, he/she should be ableto make a distinction between right and wrong. All agents in a free condition must understand right and wrong. The concept of an ideal speech situationis an inter-agent discussion in an open and equal state (in Geuss, 1981, p. 65).

Haraldo de Campo, a Brazilian translator, states that translation is a dialogue, and the translator is thepowerful independent reader(in Bassnett \& Trivedi, 2002, p. 5). The discussion referred to by Campo is a kind of negotiation, which Siponkoski also describes:

... translation solutions in published translations must be seen as outcomes of the habitusgoverned practice of negotiation that takes place between the translator and the other agents in the course of the editing process. From a theoretical point of view, negotiation has been dealt with in terms of strategic decision-making on the part of the translator, and a parallel has been drawn between translation strategies and negotiation. Negotiation was then dealt with on two levels, the macro- and the microlevel (2013, p. 35).

Negotiation activities in translation are a web of power relations. Besides the factor translator and editor, other factors also play a significant role in determining the translation results, namely the power relations, which can be both economical and ideological (Hasyim, M., Kuswarini, P., \& Kaharuddin. 2020).This research aims to examine which power dominates the translation of LP into TRT.

\section{METHODOLOGY}

This article is written based on qualitative phenomenological research. Data are translation phenomena in the form of words, phrases, sentences, paragraphs, to chapters in the ST and its corresponding items in the TT. Data are collected by first comparing the words, phrases, sentences, paragraphs, and even sections in the ST (Laskar Pelangi) with the TT (The Rainbow Troops). They are classified based on the similarity of language form and the content. Categorized data are then analyzed using the translational approach. The data analysis useda comparison of the syntactic and semantic structure of words, clauses, phrases, sentences, and paragraphs, between the ST and the TT. The results are analyzed using the concept of the relation of Self and Otherof Edward Said, and the theory of mimicry and ambivalence of Homi Bhabha, for revealing if there are indications or inclinations of retaining and upholding western values and worldview or countering and refusing them.

The first edition of the novelLP by Andrea Hiratawas published in 2005.It was a phenomenal success story. The story is aboutdeprived children of the Malay ethnic in Belitong island, an island on the eastern coast of Sumatra, Indonesia, aspired to reach a better life through education amid poverty. The narrator in this novel is Ikal, the leading character. He is the portrayal of the author himself, Andrea Hirata. Other maincharacters are Bu Mus, a young female teacher with idealism, Pak Harfan, thewise and respectable school principal, and nine pitiable children, the schoolfriends of Ikal. The determination and enthusiasm of the poor children in reaching their aspiration had touched the readers.

Andrea Hirata translated his first novel, LP, initially, by himself, then assisted by Angie Kilbane. Bentang Pustaka, Yogyakarta, published the English version of the book entitled 'The Rainbow Troops' (TRT) for the first time in 2009. The phenomenal achievement of the novel is at the same time, considered controversial. On the one hand, it was praised for bringing fresh air to Indonesian literature, especially children's literature, but some critics and literary researchers reviled the novel as too west-oriented (Ambarwati, 2015, pp. 44-45).LP tries to serve an ideal picture of the practice of Islamic life, local wisdom, as well as multiculturalism in Belitong society. However, Lina (2017, p. 18) revealed that Lintang and Mahar represent mimicry and ambivalence as both adore western lifestyle. These opposite ways of representing these characters become the base of the study of the translation of this novel. This paper examines the English adaptation of the story through a postcolonial perspective to determine how the Self exposed. The Self is the main object of this study, because of the dominant 'appearance' of the author in the translation of his novel. 


\section{JOURNA OF CRITICAL REVIEWS}

ISSN- 2394-5125

VOL 7, ISSUE 19, 2020

\section{MIMICRY IN THE FORM OF OTHERING THE SELFHYPERBOLIC DESCRIPTION OF POVERTY}

LP depicts the impoverishment of the labors of PN Timah (a national tin company), and other marginalized people in Belitong island, the eastern coast of Sumatra, Indonesia, throughout the novel.SD Muhammadiyah Gantong (an elementary school) is one of the representations of poverty. The school building was in a terrible condition, almost collapsed and the local government planned toshut the school caused by the lack of students. The following are descriptions of impoverishment presented in ST and TT.

ST: [1] Kami memiliki enam kelas kecil-kecil, pagi untuk SD Muhammadiyah, dan sore untuk SMP Muhammadiyah ... Kami kekurangan guru dan sebagian besar siswa SD Muhammadiyah ke sekolah memakai sendal. (LP, p. 17)

(the school had only six small classes, used in the morning by SD [elementary school] Muhammadiyah, and in the afternoon by SMP [middle school] Muhammadiyah...there were never enough teachers in our school and the majority of the students of the elementary school wore sandals).

TT:We only had two teachers for all subjects and grades. We didn't have a uniform. We didn't even have a toilet. Our school stood on the edge of a forest, so when nature called, all we had to do was slip off into the bushes. Our teacher would watch after us, just in case a snake bit us in the outhouse. (TRT, p. 17)

ST: [2] Kami juga tak punya kotak P3K. Jika kami sakit, sakit apa pun: diare, bengkak, batuk, flu, atau gatal-gatal maka guru kami akan memberikan sebuah pil... APC. Itulah pil APC yang legendaris di kalangan rakyat pinggiran Belitong. Obat ajaib yang bisa menyembuhkan segala rupa penyakit. (LP, 18)

(moreover, the school was not equipped with a first aid box. In case of illness, such as diarrhea, abscess, cough, cold, or irritation, then our teacher would heal us with a pill, APC. The people living in the suburb of Belitong island knew the APC pill as a wonder medicine that cures all kinds of illnesses.

TT: We didn't have first aid either...there were three large letters on the pill: APC - Aspirin, Phenacetin and Caffeine. This APC pill was legendary... this generic cure-all was the government's solution to make up for the underallocation of healthcare funds for the poor. (TRT, p. 18)

The TT dramatized poverty by providing more details, as seen in data [1]. ST illustrates the misery of the school by the fact that there wasa lack of teachers and that students wore sandals to go to school. But in the TT, details such as the absence of toilets are given for dramatizing the portrait of poverty and giving the impression that they still lead primitive life.

Data [2] is not much of a difference. While ST describes APC pills, of which the production was discontinued to the risk of kidney failure (medicinenet.com., 2019), as a cure for all diseases, TT tends to describe it as a drug provided by the government for the poor.

In describing poverty in TT, the translator (also the author) uses two positions at once, namely socially as the Self, but seen through a postcolonial point of view, he is actually in the place of the Other. As the social Self, he displayed his poverty, but he took the position as the social Other, who perceived the condition from a postcolonial perspective.In this way, he acted as the Self of the postcolonial version who viewed the Other as different human beings, who are backward and impoverished. This phenomenon shows the symptom of mimicry as explained by Bhabha. According to him, the characteristics of mimicry are "repetition, not representation" (1994, p. 88). Translator, who at the same time was the author himself, made repetitions of the description of eastern societies, ex-colonized countries who are poor, and primitive, even though he is part of that society. The phenomenon is the irony that Bhabha describes it as "the desire to emerge as authentic through mimicry through a process of writing and repetition" (1994, p. 88).

\section{REDUCTION OF MALAY ISLAMIC TRADITION BY DELETING ISLAMIC NAMES}

Castration of the character naming referring to Arabian tradition hid the traces of significant influences of Islam on the Malay ethnic in Belitong. The attribute 'bin'(for men) and 'binti' (for women) signify that the bearer is the son or the daughter of the name following both attributes. The Malay tribe has implemented this naming in particularregions of Sumatra. 


\section{JOURNA OF CRITICAL REVIEWS}

ISSN- 2394-5125

VOL 7, ISSUE 19, 2020

ST: [4] Lebih menarik membicarakan tentang orang-orang seperti apa yang rela menghabiskan hidupnya bertahan di sekolah semacam ini. Orang- orang itu tentu saja kepala sekolah kami Pak K.A. Harfan Efendy Noor bin K.A. Fadillah Zein Noor dan Ibu N.A. Muslimah Hafsari Hamid binti K.A. Abdul Hamid. (LP, p. 20)

(It is more interesting to talk about people who sacrifice their lives to bear the poor condition of the school. They were undoubtedly our principal Mr. K.A. Harfan Efendy Noor bin K.A. Fadillah Zein Noor and Mrs. N.A. Muslimah Hafsari binti Hamid K.A. Abdul Hamid.)].

TT: What is more interesting is the people who dedicated their lives to ensuring the survival of a school like this. Those people are none other than our school principal, Pak Harfan, and Bu Mus(TRT, p.21).

The TT doesn't show the attributes of the names. Name is also a part of culture. Translating names should be seen as an attempt to bring the culture of the ST into the world of the TT readers. The importance of translating names is that the cultural gap between the speaking cultures (can be) diminished (Leskovar, 2017, Arafah, B., Jamulia. J., \& Kaharuddin. 2020), and because names stand for both as a celebration and a restriction of identities(Cheng, 2014). Ignoring names means ignoring the very substantial part of literature, namely culture (Bahar, A. K., \& Latif, I. 2019, Hasyim, M., Nursidah,\&Hasjim, M., 2019). The loss of the family names of the characters in the TT causes the damage of their cultural, social and even ideological identities.

IslamenteredtheIndonesianarchipelagoinfiveperiods,startingfromthebeginningof

the13thcentury tothe20thcentury.Thefirstperiodistheperiodofintroductionofrulesor

'fiqh.'ThesecondperiodhasmadeIslamareligionthatconsciously

practiced,notjustasa formality.Sincethesecondperiod(thelate15thcenturytothe16thcentury), Islamhascolored the intellectuallife in the archipelago.Inthe third period (from the 17th century),Islamhas becomeapartofallaspectsoflifeandculture(Huda,2016, p. 82). EventheprominentIslamic literaturewashighly developedinSumatrainthe17thcentury.Itisthereforenotsurprising thattheMalaytribesinsomeareasofSumatraadoptedthe way of naming fromtheArabian Islamicculture.

Nameas a representationofculturalidentityis also shown bythe examplebelow:

ST [5]: TingkahinidiikutiSaharayangsengajamenumpahkanairminumAKiongsehingga anakHokian itumenangis sejadi-jadinya...N.A.SaharaAuliaFadilah bintiK.A. MuslimRamdhaniFadillah, gadiskecil itu, memangkeraskepala luar biasa (LP, p. 14).

(Thisbehavior followedbySaharawhodeliberatelyspilledthedrinkingwaterofA Kiong so that theHokian boywascrying out loud... N.A. SaharaAulia Fadilah bintK.A. RamdhaniMuslimFadillah, thelittlegirlwas, indeed unusuallystubborn.)

TT:Ontopofthis,Sahara, thatsmallgirl,deliberatelyknockedoverAKiong'swaterbottle,causingthe Hokian-Chinese childto cry...Saharawasextraordinarilyhard-headed. (TRT, p. 15)

Thecontextofthequotation aboveisthe atmosphereofadmissionofnewstudentsatSD Muhammadiyah Gantong, Belitong Island.Theschoolcould getonlytennewstudents. Butthe uniquenessoftheIslamicschoolis theacceptanceofnon-MuslimdisciplesofChinese descent,A andN.A.SaharaAuliaFadilahbintK.A.MuslimRamdhani Kiong.ThenameAKiong poorschoolwasarepresentationof Fadillahwereunitedtoshowthatthe upholdpluralism.ThereductionofSahara'snameblurredthepictureofthe"culturalcontrast."

AKiongrepresentstheIndonesianChinesecommunity, whichhasspecificculturalimagesand stereotypes, whileSahara,withher Islamicname, isarepresentationof theIslamicMalay community, which also hasfirmportrayals. Cutting a name means hiding the crucial signifier of identity, as stated by Hall (1990): 'losing a name would deform a person's cultural identity and produce an 'individual [...] without an anchor, without horizon, colorless, stateless, rootless' (qt. in Alter, 2016, p. 9).

AsasignificantelementoftheexistenceofMalaypeopleinBelitong, IslamisexposedintheST i.e.due toareportofthegreat effort ofaMuslimindividualnamedZubairbinAwamin developingtheMuhammadiyahschool.Thedescriptionistransformedintoasufferofthe initiatorsoftheschool,whopressuredbytheDutchcolonial government and neglected by the Indonesian, asdescribed inthefollowing quote.

ST [6]:Kamimenantilikudemi liku ceritadalamdetik-detik menegangkandengandada berkobarkobaringinmembelaperjuanganpenegakIslam.LaluPakHarfanmendinginkan 


\section{JOURNA OF CRITICAL REVIEWS}

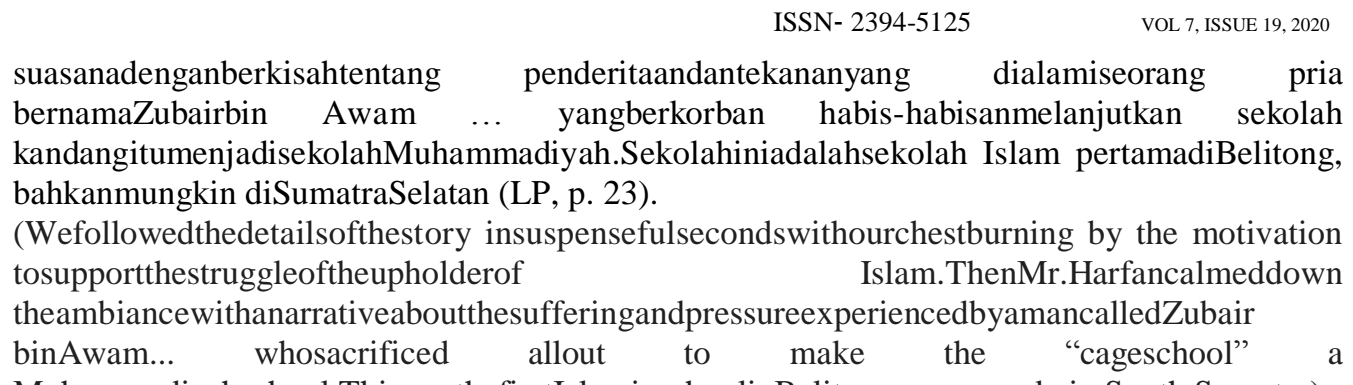

Muhammadiyahschool.ThiswasthefirstIslamicschoolinBelitong,even maybein South Sumatra).

TT:Weleanedforward,waiting formore, strainingourspiritedchestswanting to defend thestruggleofour religious forefathers. ThenPakHarfancooleddownthemoodwitha storyofthesufferingexperienced bythefoundersofourschool-howtheywere suppressed by the colonialDutch, abandoned bythegovernment,cared aboutbyno one, butstood firm to pursue theirbig dreamsforeducation (TRT, p. 25).

Thename 'ZubairbinAwam'isreplacedwith: theroleofthecharacterinbuildingthecultureofhissociety nameofZubairbinAwammustbe impliedaparticularthought,belief, theidentityoftheMuhammadiyahschool andinternalizedintothesoulsofeachofitsdisciples. The name Zubair bin Awamrepresented the ideology of Muhammadiyah in Belitong.

The expression: "...withourchestburning by the motivation tosupportthestruggleoftheupholderof Islam is replaced with: "...wanting to defend the religious struggle of our forefathers." The attempt of the Islamic group in enhancing education is to build an Islamic school as seen from the quotation: "Who Sacrificed all out to continue the building of the "cage school'became Muhammadiyah school." The TTsimplified the term Islamic school is into "common education": "Stood firm to pursue their big dreams for education."

In the post-colonial context, Islam for Europe (West/ colonizers) "symbolize terror, devastation, the demonic, hordes of hated barbarians" (Said, 2003, p. 60). The translator's act in hiding the role of Islam in shaping Malay culture is most likely to avoid the resistance of the TT readers. The tendency shows that the translator is more concerned about the opinions of the West than presenting his true identity. That is the characteristic of mimicry, as Bhabha states: "What emerges between mimesis and mimicry is a writing, a mode of representation, that marginalizes the monumentality of history..." (1994, p. 88).

\section{CREATION OF LOCAL FEMALE HERO}

The Story about the young female teacher, Bu Mus, is added to the TT as a new chapter. It is the story about her fight against the PN Timah, against the plan of the tin company to occupy the land where the Muhammadiyah school existed. The chapter is entitled: A Young Girl Challenges the King (pp.359-369), obviously constructed to intensify the image of people's deterioration and corrupt government, as depicted by the following quotation:

At that time, opposing those in power was taboo. The powerful was that strong. Many critical voices had mysteriously disappeared (TRT,p. 360)

The heroic act of Bu Mus additionally emphasizes the image of the totalitarian and dirty government of Indonesia as a portrayal of the East. This part shows that social injustice is a part of the daily life of Indonesian people. Authoritarianism carried out by PN Timah is a representation of the government and its powerful cronies, as shown by the phrase: "opposing those in power was taboo."The terrible portrait is in line with the opinion often stated by the West, as referred to Said when he criticized the conception of Arthur Balfour, the British prime minister who governed from 1902 to 1905. On the word of Balfour, the East would never enjoy the glory under oppression and dictatorship (Said 2003, pp. 32-34). The sentence: "Many critical voices had mysteriously disappeared," depicted Indonesian tyranny.

The fight of Bu Mus against the tin company reminds us of the Hollywood film 'Erin Brokovich (2000)'. That is a film about a young single mother, a marginalized woman who dared to fight against a prominent real estate firm. Bu Mus, a poor young female teacher who did not have anything but the spirit to serve poor children, is an ideal character to be exploited as a sympathy gainer. A poor and young woman is a perfect opponent against the masculine economic giant. The picture of Bu Mus's struggle is also a kind of repetition, a part of the mimicry symptom. 


\section{JOURNA OF CRITICAL REVIEWS}

ISSN- 2394-5125

VOL 7, ISSUE 19, 2020

\section{CONCLUSION}

As teenage love stories filled Indonesian literature, readers saw LP, a based-on-a-true-story novel, as something new and fresh. It was successful in depicting how elementary school children living on an underdeveloped island with all their constraints however showing their 'joie de vivre.' Nevertheless, this study reveals that labeling is overused when it comes into its translation into English by exaggerating the subordination of the social self' (Indonesia /the East): pitiable, filthy, uncivilized. Besides, the domination of Islamic culture in Malay society is less shown, if there is any, by eliminating family names and the fact that Islamic leaders struggle in advancing education. The negative image of Islam in the West could be the background of the castration.The supplement of a new episode in the TT on the fight of Bu Mus against the PN Timah can be seen as an additional try to magnetize the responsiveness of Western readers. This addition strengthens the mark of the crooked and dictatorial East as the West always perceives it.

Compared to the efforts of African authors who also translate their works in the language of the dominant power but put themselves on an equal footing with their colonizer through translation strategies, Andrea Hirata looks like losing confidence in dealing with the West. He prefers to hide the identity of the Malay tribe, even though it reflects Indonesia's cultural wealth. He alsoallowed the West to confirm the stereotypes they embed on the East, where he used the Western perspective to analyze his condition. That indicates the symptom of mimicry. His interaction with European culture and way of life led him to be a mimicry of them. He exploited the inferiority of the people he belongs to, for fulfilling the imagination of the West about the East.

After studying self-translations by post-colonial writers, the translation of LP into TRT shows an unusual phenomenon. It is against the general tendency of postcolonial translation that always tries to promote equality in presenting the identity and the existence of the formerly colonized nations. The conversion of LP in English seems to legitimize Western view against the East expressed through the practice of stereotyping, in this case, othering the social Self.

Colonialism experienced by Indonesian over three centuries psychologically left a symptom called 'minderwardigheids' complex or low self-esteem syndrome (Sulistiyono, 2018, p. 5). It is a feeling of being less worthy than other people. Indonesian internalizes the symptom in various ways, such as tradition, education, politics, to the world of entertainment (Bahar, A. K. 2013, Arafah, B., \& Kaharuddin, 2019). Every Idul Fitri feast Indonesian serves traditional dishes, but Dutch cakes and cookies always reflect social standing. In the world of higher education, Indonesians see overseas graduates are more elevated than domestic graduates. Indonesian film industry uses the service of semi-Eurasian faces that are considered more beautiful and handsome. Such a perspective was also evidenced in Malaysian higher education. Malaysian local English teachers, compared to native speakers, were always suspected as not teaching English properly (Kesevan, 2018, p. 20). However, interestingly, Malaysian Millennials think that 'native, speakers' in language teaching are a must, but they should not be mentioned as 'Westerners' which sounds negative (Litowski,2018, p. 49).This phenomenon reflects inferiority, which then becomes a way of looking at oneself and others. The Selfis not great, and others are better. This perspective is served and sold to Western readers by Andrea Hirata as the initial translator of his novel, 'Laskar Pelangi.'The western public certainly is entertained with the familiar image which is following their beliefs. We can assume that it fulfills the market's interest. The purpose of this finding is to raise translators' awareness, to empower them, that they should work with idealism and principles, that the position of all nations, languages, and cultures in the world is equal.

\section{REFERENCES}

[1] Adibah, Dzakiyyatul. (2012). An Analysis of Metaphor Translation in the Novel "Laskar Pelangi" by Andrea Hirata. Unpublished Master thesis, Institut Agama Islam Syekh Nurjati, Cirebon, Indonesia.

[2] Alonzo, Elizabeth Hipolito. (2019). Ibanag Identity and Worldview through Songs: A Critical Discourse Analysis. The Asian ESP Journal Vol. 15, (1.2),82.

[3] Alter, Grit. (2016_. What's in a Name? Assimilation Ideology in Picturebooks. CLELE Journal: Children's Literature in English Language Education. Vol. 4 (1), 2

[4] Ambarwati, Mei. (2015). Western Colonization Towards Indonesian People Reflected in Andrea Hirata's The Rainbow Troops. Unpublished Master thesis, Universitas Negeri Semarang, Semarang, Indonesia.

[5] Andi, K., \& Arafah, B. (2017). Using needs analysis to develop English teaching materials in initial speaking skills for Indonesian college students of English. The Turkish Online Journal of Design, Art and Communication (TOJDAC), Special Edition, 419-436.

[6] Andindilile, Michael. (2013). Beyond nativism: Translingualism and Ngugi's engagement with anglophonism. Perspectives: Studies in Translatology. Vol. 22 (2), 194.

[7] Andrade, Claudia Braga. (2016). Derrida's writing: Notes on the Freudian model of language: Psicologia USP, Vol.27(1). Retrieved April 1, 2019 fromhttp://www.scielo.br/scielo.php?pid=S010365642016000100096\&script=sci_arttext\&tlng=en 


\section{JOURNA OF CRITICAL REVIEWS}

ISSN- 2394-5125

VOL 7, ISSUE 19, 2020

[8] Arafah, B. \& Hasyim, M. (2019). Linguistic functions of emoji in social media communication. Opcion. Vol. 35 (24), 558-574.

[9] Arafah, B., \& Kaharuddin, (2019). The Representation of Complaints in English and Indonesian Discourses. Opción, 35, 501-517.

[10] Arafah, B., Jamulia. J., \& Kaharuddin. (2020). The Speaking People of South Halmahera Languages: A study on Cultural Relationship. Journal of Talent Development and Excellence, 12(3s), 1331-1340.

[11] Bahar, A. K. (2013). The Communicative Competence-Based English Language Teaching. Yogyakarta: TrustMedia.

[12] Bahar, A. K., \& Latif, I. (2019). Society-based English community (sobat): EFL learners'strategy in learning and practicing English outside the walls. Jurnal ilmu budaya, 7(2), 255-265.

[13] Barker, Chris. (2003). Cultural Studies: Theory and Practice. Thousand Oaks, New Delhi: Sage Publication.

[14] Bandia, Paul F. (2008). Translation as Reparation: Writing and Translation in Postcolonial Africa. London, New York: Routledge.

[15] Bassnett, Susan \& Harish Trivedi (2002). Post-Colonial Translation. London, New York: Routledge.

[16] Bhabha, Homi.K. (1994). The Location of Culture. New York: Routledge.

[17] Callahan, David. (2015). Race and Identity in D.H. Lawrence: Indians, Gypsies, and Jews. Journal of Postcolonial Writing. Vol. 51 (2), 251.

[18] Chandran, Gheeta and Ravichandran Vengadasamy. (2018). Colonialist narrative in a post-colonial era travel writing, into the heart of Borneo. GEMA Online Journal of Language Studies. Vol.18 (4), 18.

[19] Cheng, Franziska. (2014). Jacques Lacan and The Intrinsic (Un)translatability of Names: "Name" in the English-Chinese Translation of Winterson's Art \& Lies. New Voices in Translation Studies. Vol. 11, 117.

[20] David 2016 in https://www.goethe.de/ins/id/ (accessed on the 20th of April 2016).

[21] Geuss, Raymond (1981). The Idea of a Critical Theory: Habermas and the Frankfurt School. Cambridge, London, New York: Cambridge University Press.

[22] Gjurčinova, Anastasija. (2013). Translation and Self-Translation in Today’s (Im)migrant Literature. CLCWeb: Comparative Literature and Culture. Vol. 15 (7), 5.

[23] Goluch, Dorota. (2018). Solidarity, Translation, and Postcolonial Literature in Polish. Retrieved April 1, 2019 fromhttps://www.euppublishing.com/doi/abs/10.3366/ccs.2018.0275

[24] Hamadi, Lutfi. (2014). Edward Said: The Postcolonial Theory and The Literature of Decolonization. European Scientific Journal. Vol. 2, 40.

[25] Hasyim, M., Nursidah,\&Hasjim, M., (2019). Online advertising: how the consumer goods speaks to women. Opcion. Vol. 35 (89), 826-845.

[26] Hasyim, M., Kuswarini, P., \& Kaharuddin. (2020). Semiotic Model for Equivalence and Non-Equivalence In Translation, Humanities \& Social Sciences Reviews, 8, (3), 381-391

[27] Hirata, Andrea (2005). Laskar Pelangi. Yogyakarta: Bentang Pustaka.

[28] Hirata, Andrea. 2005. The Rainbow Troops (translated by Angie Kilbane 2009). Yogyakarta: Bentang Pustaka.

[29] Huda,Khairul. 2016.IslamMelayudalamPusaran Sejarah: Sebuah Transformasi Kebudayaan MelayuNusantara.Toleransi: Media KomunikasiUmat Beragama.Vol. 8 (1), 82.

[30] Kaharuddin, A., \& Latif, I. (2017). The Essential of Discourse Analysis for Teaching English as a Foreign Language. Yogyakarta: Trust Media Publishing.

[31] Kaharuddin, A. (2018). The communicative grammar translation method: a practical method to teach communication skills of English. ETERNAL (English, Teaching, Learning, and Research Journal), 4(2), 232-254.

[32] Kaharuddin., \& Hasyim, M. (2020). The Speech Act of Complaint: Socio-Cultural Competence Used by Native Speakers of English and Indonesian. International Journal of Psychosocial Rehabilitation, 24(6), 14016-14028. doi: 10.37200/ijpr/v24I6/pr261351

[33] Kesevan, Hema Vanita. (2018). Classroom Ideologies and Teaching Styles in Post-Colonial English Classrooms. The Asian EFL Journal. Vol. 20 (10), 20.

[34] Khanal, Navadeep. (2012). The lens of postcolonial theory in lis research and practice. Ph.D.thesis in Philosophy in Library \& Information Science, University of Illinois at Urbana-Champaign), Retrieved April 20, 2019, from https://core.ac.uk/download/pdf/10208601.pdf

[35] Kirkley, Laura. (2013). The question of language: Postcolonial translation in the bilingual collections of Nuala Ní Dhomhnaill and Paul Muldoon. Translation Studies. Vol. 6 (3), 290.

[36] Leary, Mark.R \& June Price Tangney [Eds]. (2012). Handbook of Self and Identity. New York, London: The Guilford Press.

[37] Leskovar, Darja-Mazi. (2017). Names in Literary Translation: A Case Study of English VersionsoftheSlovenian TaleMartinKrpan.Acta Neophilologica.. Vol. 1(2), 150.

[38] Lina, Hana. (2017) in https://pingpdf.com/pdf-mimicry-and-ambivalence-in-andrea-jurnal-unesa.html 


\section{JOURNA OF CRITICAL REVIEWS}

ISSN- 2394-5125

VOL 7, ISSUE 19, 2020

[39] Litowski, Tana Jaclyn. (2018). Investigating Preferred English Teacher Characteristics of Asian Millennial Students.The Asian EFL Journal. Vol. 20 (8), 49.

[40] Maknun, T., Hasjim, M., Muslimat, M., \& Hasyim, M. (2019). The form of the traditional bamboo house in the Makassar culture: A cultural semiotic study. Semiotica, 1(ahead-of-print).

[41] Maroni, Maroni. (2012). Problema Penggantian Hukum-hukum Kolonial dengan Hukum-hukum Nasional sebagai Politik Hukum. Jurnal Dinamika Hukum. Vol.12 (1), 89.

[42] Orsini, Francesca \& Neelam Srivastava. (2013). Translation and the Postcolonial. Interventions: International Journal of Postcolonial Studies. Vol. 15 (3), 324.

[43] Said, Edward. 2003. Orientalism. London: Penguin Books.

[44] Shamma, Tarek. (2009). Postcolonial Studies and Translation Theory. MonTi. Monografias de Traducción e Interpretación. Vol. 1., 185-186; 192.

[45] Shamsie, Muneeza. (2011). Duality and diversity in Pakistani English literature. Journal of Postcolonial Writing. Vol. 47 (2), 119.

[46] Siponkoski, Nestori. (2013). Translators as Negotiators: a case study on the editing process related to contemporary Finnish translation of Shakespeare.New Voices of Translation Studies. Vol. (9), 35.

[47] Sohrabi, Zohreh \& Hossein Pirnajmuddin. (2017). John Donne's Metaphors of Self and Empire: A Cognitive Analysis. 3L: The Southeast Asian Journal of English Language Studies. Vol. 23 (1), 15.

[48] Yasin, Burhanuddin, et al. (2018). Analyzing the English Translation of the Novel "Laskar Pelangi" (The Rainbow Troops), Studies in English Language and Education. Vol. 5 (1), 58-59.

\section{ABOUT THE AUTHORS}

Prasuri Kuswariniis a senior lecturer at the Faculty of Cultural Sciences, Universitas Hasanuddin, in Makassar, Indonesia. Her main subjects are translation studies and literature and, she has done researches mainly on literary translation. Her other interests are German Language and literature.

Muhammad Hasyim is also a senior lecturer at the Faculty of Cultural Sciences, Universitas Hasanuddin, in Makassar, Indonesia. He teaches French, Translation, and Semiotics. He is also interested in Tourism and did several kinds of research on the subject.

Irma Nurul Husnal Chotimah is a junior lecturer at the French Department, Faculty of Cultural Sciences, Universitas Hasanuddin in Makassar, and an active translator for several institutions. 